\title{
Web Communications of Environmental Sustainability Initiatives at Sport Facilities Hosting Major League Soccer
}

\author{
Cheryl Mallen ${ }^{1}$, Chris Chard ${ }^{1} \&$ Iain Sime ${ }^{1}$ \\ ${ }^{1}$ Brock University, St. Catharines, Ontario, Canada \\ Correspondence: Chris Chard, Department of Sport Management, Brock University, St. Catharines, Ontario, \\ Canada. E-mail: cchard@brocku.ca
}

Received: March 22, 2013

Accepted: April 24, 2013 Online Published: July 3, 2013

doi:10.5539/jms.v3n3p115

URL: http://dx.doi.org/10.5539/jms.v3n3p115

\begin{abstract}
We are living in times of tremendous ecological change (Winn \& Kirchgeorg, 2005). In response, the United Nations (UN) promotes a movement towards safeguarding the natural environment or environmental sustainability (ES). Sport has not been immune from the challenges of ES and, thus, the guiding research question of the current investigation was: How does sport communicate its participation in environmental sustainability (ES)? To answer this research question this study focused on sport facilities that were home to a professional Major League Soccer (MLS) franchise during 2011; specifically, the analysis focused on the facilities' website communications on ES. This investigation utilized a content analysis process for data collection that involved four steps framed with an adaptation of the design by Krippendorff (1980) and Weber (1985). Data analysis was framed with the principles of environmental performance by Glavič and Lukman (2007) as well as ES components by Mallen and Chard (2012). The results showed that sport facilities communicated a pattern towards some ES action; specifically, renewable resource use, resource minimization, and recycling were communicated as the key areas of focus for sustainability.
\end{abstract}

Keywords: sport facilities, environmental communication, environmental sustainability, Major League Soccer

\section{Introduction}

We are living in times of "massive discontinuous ecological change" (Winn \& Kirchgeorg, 2005, p. 233) and the authoritative United Nations Environment Programme (UNEP) Intergovernmental Panel on Climate Change (IPCC) (2007) and UNEP Global Environment Outlook 4 (2007) offer evidence that human activities are responsible for generating negative environmental changes and conditions. According to the UN World Commission on Environment and Development, specifically the Brundtland Report (1987), a response to environmental conditions requires a focus on sustainability. The concept of environmental sustainability (ES) or safeguarding the natural environment, involves "meeting the needs of the present generation without compromising the ability of future generations to meet their own needs" (UN Brundtland Report, 1987, p. 1).

In this sense, sport has not been immune from ecological challenges and thus the guiding research question for this study is: How does sport communicate its participation in environmental sustainability (ES)? To partially answer this question, this manuscript provides data from website ES communications by sport facilities that were home to a professional Major League Soccer (MLS) franchise in 2011.

\subsection{Sport and Environmental Sustainability (ES)}

The management literature indicates that "a new competence in environmental management" (Starik \& Marcus, 2000, p. 540) is needed. Challenges arise however when interpreting ES - as it is context specific (Barth, Godemann, Rieckman \& Stoltenbert, 2007; Heugens, 206), difficult to navigate (Schwartz, 2009), considered complex (DeTombe, 2005; Mallen, Stevens \& Adams, 2011; Olstoorn, Tyteca, Wehrmeyers \& Wagner, 2001) and operates with an evolving baseline of environmental performance (Shriberg, 2002). According to Olstoorn et al. (2001) "each set of [environmental performance] indicators should be specific to the organizational context and the information requirements of the user" (p. 461). For sport management, this means that sport specific understandings concerning ES are needed for each of the multiple contexts including the professional, semi-professional and non-professional sport competition spheres, along with multiple sub-sectors such as sport 
and law, marketing, finance, sponsorship, facility and event management. Yet, little is known about the response to ES by sport.

\subsection{Sport ES Literature}

While few sport management manuscripts have specifically examined sport and ES (Mallen et al., 2011), the majority that do continue to encompass sport environmental sustainability within the general concept of Corporate Social Responsibility (CSR). This manuscript, however, promotes that ES is a large and complex topic that needs to be studied specifically.

Recently, Paquette, Stevens and Mallen (2011) examined ES based on understandings by the International Olympic Committee (IOC) and the Organizing Committees of the Olympic Games (OCOG's) and noted the multiple interpretations on the natural environment. These interpretations ranged from organizations being adaptive to safeguarding the environment to those being detrimental to its future sustainability. Mallen, Stevens, Adams and McRoberts (2010) examined the environmental performance of an international multi-sport event and found a high level of effort but a low level of results. These low results were due to a lack of monitoring and management during the implementation time period. In addition, Mallen and Chard (2011) framed a debate on sport ES and another Mallen and Chard (2012) manuscript established a vision of "what could be" in sport facility ES. Further, a list of research conducted on sport and ES was generated in a content analysis that examined an extensive sample of 21 sport management journals published from 1987 to 2008 (Mallen, et al., 2011). This manuscript provided an overview of the history of sport's involvement in ES, including advancing world conferences and International Olympic Committee involvement, along with the research record on ES from within the sport management academy. The manuscript concluded that while sport was still in the infancy stages of ES, there has been a shift from general concerns about the natural environment to emphasizing "ES problem solving and success" (p. 252), including managerial prioritization of initiatives such as shaping brand perceptions through communications.

\subsection{Brand Theory and Sustainable Communications Applied to Sport}

Miloch and Pederson (2006) note the relationship that sport has historically shared with mainstream media. Indeed, the media has been influential in shaping perceptions about sport organizations, especially in the $20^{\text {th }}$ Century, through their discourse. More recently however the ability to utilize web communications and social media "present(s) unique and distinct advantages for sport entities because they are able to communicate unfiltered messages directly to consumers (Wallace, Wilson, \& Miloch, 2011, p. 22). This direct communication provides sport managers with a powerful medium to shape brand perceptions and enhance relationships with all stakeholder groups. Indeed, brand perceptions are formed wherever a "brand interacts with, and makes an impression on, customers, employees, and other stakeholders" (Davis \& Dunn, 2002, p. 58). Here, brand theoreticians have long extolled the benefits of strong brands to enhance loyalty for both general and sport specific businesses (Aaker, 1996; Berry, 2000; Gladden, Milne, \& Sutton, 1998). As such, utilizing all organization-to-stakeholder communication channels (i.e. web communications) to promote brand-building initiatives could assist in enhancing brand loyalty. Examples of ES initiatives that could form part of a sport facility manager's sustainable communications will be offered next.

\subsection{Strategies for Environmental Sustainability}

An example of sport managers strategically responding to ES challenges includes the use of environmental certification programs. One such program, the Leadership in Energy and Environmental Design (LEED) certification, concerns building construction. This program provides "reliable building-rating and performance measurement systems for new construction and renovations [that] has helped change corporate perceptions about green" (Lockwood, 2006, p. 213). LEED awards points for specific categories such as for the building site and its proximity to public transportation, the buildings water and energy efficiency and reuse and recycling of materials during the building or retrofitting process. According to the United States (U.S.) Green Building Council (n.d.), "An upfront investment of $2 \%$ in green building design, on average, results in life cycle savings of $20 \%$ of the total construction costs - more than ten times the initial investment" (n.p.). LEED, however, has not been noted as instrumental in guiding the growth of ES at existing North American sport facilities due to cost, time, bureaucracy and funding barriers (Mallen, Adams, Stevens \& Thompson, 2010). This may be changing however as the first gold level certification for an existing sport venue (that was retrofitted) was earned in 2011 at the Rose Garden arena in Portland, Oregon (AEG, 2012). 
Other ES certification programs involve the International Standards Organization (ISO), such as ISO 9001 (Quality Management) and ISO 14001 (Environmental Management). To participate in these standards initiatives, organizations purchase existing management documents and implement their self-determined strategies to meet the standards. Research by Darnall and Sides (2008) however found that ISO $14001 \mathrm{had}$ inconclusive performance gains. Importantly, a reason for this result may be found in the note provided on the ISO webpage that performance and protecting the environment is industry specific (ISO 14004, 2004, n.p.) and interpretations concerning decisions for successful ES implementation are still being negotiated. Indeed, highlighting this case-by-case perspective, a sport specific ISO was devised for the 2012 London Olympic Games. This newly formed ISO has the potential to be beneficial to sport facilities around the world.

Further, the Anschutz Entertainment Group (AEG) manages and operates several major North American sport facilities, such as the Staples Center, Home Depot Center, Rose Garden and also owns varying percentages of two MLS clubs (the Houston Dynamo and Los Angeles Galaxy). AEG offers environmental goals on their website and provides a 2010 environmental sustainability report and measurements of their environmental performance. These goals and reports are offered to encourage facilities and the clubs they manage to be involved in environmental sustainability (AEG, 2010; 2012). Another company that manages and operates North American sport facilities is Global Spectrum. This company has devised the Global Spectrum Total Environmental Plan (STEP UP) that encourages their sport facility managers to save energy, reduce, reuse and recycle. The aim of STEP UP is to reduce the overall environmental impact of sport facilities on the natural environment.

Additional examples of individual sport facility ES problem solving strategies include a joint venture at Chase Field, in Phoenix, Arizona in conjunction with the local utility called the Arizona Public Service; here "a 17,000-square-foot solar canopy" (Belson, 2011, para. 5) was built to create energy efficiencies. Also, managers at the FedEx Forum, in Memphis, Tennessee, established a system to "cleanse the water used to wash down the stands before it goes back into the Anacostia River next to the site" (Muret, 2006, p. 59). Further, the National Association for Stock Car Auto Racing (NASCAR) adapted their operations to utilize "hybrid vehicles as pace cars and the planting of 10 mature trees after every race... [and have switched to fuel with] a 15 percent ethanol blend" (Belson, 2011, para 13).

In light of the examples of sport and ES, this manuscript now outlines MLS. Next, the research's methodological framework for this examination of sport facilities that were home to a MLS franchise during 2011 and their website communications on interpretations of ES is presented. The results and discussion follow before the study's conclusion is offered.

\subsection{Major League Soccer (MLS)}

MLS announced its formation in 1993 as part of an agreement with Fédération Internationale de Football Association (FIFA) that a professional soccer league would be started in the United States to go along with its World Cup bid (MLS, 2008). The league began in April 1996 as the San Jose Clash defeated DC United 1-0 in front of 31,000 fans (MLS, 2008). MLS operates as a single, limited liability company (single entity) - owners operate their club but possess a financial stake in the league - not in their specific club (MLS, 2008).

The league began with seven clubs in its first season and grew to 18 clubs in 2011 (housed in 17 sport facilities as the Los Angeles Galaxy and Chivas USA both play out of the Home Depot Center). The league was sub-divided into two conferences with 9 clubs in the eastern conference and 9 clubs in the western conference. The clubs within the two conferences were extensively housed in the USA, but two clubs extended the league into Canada.

Don Garber has been commissioner of the MLS since 1999 and despite the growth in the number of clubs, MLS reportedly suffered large financial losses in their early years (MLS, 2011a). According to Business Week the clubs lost $\$ 350$ million between 1996 and 2004 (Holmes, 2004). Clubs are now, however, beginning to turn a profit as in 2006 FC Dallas and the Los Angeles Galaxy were the first profitable clubs and two years later Toronto FC ran a profitable organization (Badenhausen, 2008; Longman, 2007). In 2011 MLS passed both the National Basketball Association (NBA) and the National Hockey League (NHL) to become America's $3^{\text {rd }}$ most attended sport and was rated as the $10^{\text {th }}$ most attended soccer league in the world (Huffington Post, 2011), representing a 23\% increase in attendance since its inaugural season in 1996.

Commissioner Garber has also been the driving force behind the influx of the construction of soccer specific stadiums. During his term as commissioner there have been ten soccer specific stadiums built for MLS use, 
including BMO Field, Columbus Crew Stadium, Dick's Sporting Goods Park, FC Dallas Stadium, Livestrong Sporting Park, PPL Park, Red Bull Arena, Rio Tinto Stadium, Home Depot Center, and Toyota Park. Also, two facilities have been renovated for soccer purposes, including BC Place and Jeld-Wen Field.

Finally, in 2007 Commissioner Don Garber started MLS W.O.R.K.S., a community outreach program dedicated to tackling important social issues, including the need to run an environmentally friendly league (MLS, 2011b). One of W.O.R.K.S. programs is "Greener Goals" that sets us community programs with help from the different clubs with a goal to educate the soccer community on the importance of environmental sustainability (MLS W.O.R.K.S., 2011). Eleven clubs are actively participating in "Greener Goals" by raising awareness either in their stadium during a game or out in the community (MLS W.O.R.K.S., 2011). Chivas USA, a Los Angeles based club, has taken the lead in "Greener Goals" by participating in a three part campaign that asks sponsors, local students and fans to participate in an elementary school recycling contest, a beach cleanup and a "Green" soccer match that took place on April 30, 2011 (MLS W.O.R.K.S., 2011).

It is also important to note that the 2011 All-Star game hosted at the Red Bull Arena in New Jersey was run in an environmentally friendly manner. For this game, MLS and its sponsors worked to offset the carbon impact of the event by purchasing enough renewable energy certificates from Bonneville Environmental Foundation to offset the power used during the game (MLS Soccer, 2011). Indeed, the carbon dioxide reduction value from this game could power a U.S. house for 9 years (MLS Soccer, 2011). Renewable energy certificates were also purchased for all MLS matches during Greener Goals Week in 2011 and this represented offsets of over 2 million pounds of carbon emissions.

\section{Case Method}

This case study involves an examination of sport facilities that were home to a MLS franchise during 2011 and their website communications on interpretations of ES. Yin (1994) purports that the case study research design method seeks to explain "links in real-life interventions that are too complex for the survey or experimental strategies (p. 15). Also, Yin indicates that this research strategy is suited to research questions that concern the "how" and "why" of the case. Further, the content analysis methodology involves a "research technique for making replicable and valid inferences from texts (or other meaningful matter) to the contexts of their use" (Krippendorff, 2004, p. 18) by systematically generating understandings concerning, in this examination, the extent of the ES movement within the case.

\subsection{Data Collection}

The four steps in the content analysis data collection methodology were based on an adaptation of work designed by Krippendorff (2004) and Weber (1985) and utilized in Mallen et al. (2011). The first step involved establishing the sampling units (the 17 sport facilities that host the 18 MLS clubs - see Appendix A). The second step involved determining the unit of text (the environmental communications on the website of each sport facility). The third step involved establishing the coding themes and subthemes. These were derived from a comprehensive environmental measurement tool called the Sport Event Environmental Performance Measurement (SE-EPM) designed by Mallen et al., (2010). The fourth and final data collection step involved determining the coding mode. Human coding was utilized and entailed a manual search of the communications concerning ES on the website of each sub-case (MLS facility). Human coding was utilized to accommodate situations whereby "some words may have multiple meanings" (Stemler, 2001, para. 9). For triangulation purposes, two members of the research team conducted the search independently. The research team compared data, identified discrepancies and resolved coding decisions.

\subsection{Data Analysis}

Data analysis was framed with components by Mallen and Chard (2012) that include: innovations in sustainability; efficient and effective use of energy and resources; reductions in waste and pollution; the utilization of renewable energy; reductions in air pollution; water stewardship; safeguarding land and promoting sustainability. These components were supported by Patton's (2002) proposal that the analysis be organized to allow for comparisons in the examination and to generate emergent insights. Further, the data was guided by an adaptation of the 12 foundational principles of environmental performance as outlined by Glavič and Lukman (2007) that "form an interconnected system" (p. 1884) that include:

renewable resources, resource minimization, source reduction dematerialization[redesign to reduce waste], recycling, reuse, repair, regeneration, recovery, remanufacturing, purification, end-of-pipe [ensuring purification prior to discharge], degradation, and are arranged from preventive to control principles (p. 1876). 


\section{Results}

The results of the content analysis of website environmental communications by sport facilities that hosted professional MLS games in North America during 2011 are outlined in Table 1.

Table 1. MLS sport facilities environmental communications

Sport Facility: BC PLACE; Architect: Stantec Architecture Group (AIBC, 2011); Seating: 21,500 (Constatineau, 2011) City: Vancouver, British Colombia, Canada; MLS Club: Vancouver Whitecaps; Year Joined MLS: 2011 Playing Surface: Polytan artificial turf (Constatineau, 2011).

Innovations in sustainability: BC Place underwent a massive renovation that was completed in 2011. Many of the renovations made it a more environmentally friendly stadium (BC Place, 2011a).

Reductions in Waste and Pollution, Safeguarding Land: BC Place has adopted an integrated waste management program to reduce waste and expand recycling. They also have a green cleaning policy that lightens the impact of their daily maintenance (BC Place, 2011a). Since BC Place was renovated, resources were saved that would have been used during the demolition process, land was able to be reused (BC Place, 2011a).

Efficient and effective use of energy and resources: BC Place installed energy efficient fixtures and a new lighting system that cuts lighting energy by forty percent (Crenna, 2011). The new retractable roof saves energy by twenty-five percent, which amounts to $\$ 350,000$ annually (Crenna, 2011).

Promoting Sustainability: BC Place is accessible by Vancouver's street car and SkyTrain at the Stadium-Chinatown stop (BC Place, 2011b). Starting in 2011 BC Place has pledged to go completely carbon neutral by purchasing carbon offsets from Pacific Carbon Trust. They are also improving their carbon management and are shrinking their actual carbon footprint each year (BC Place, 2011a).

Sport Facility: BMO FIELD IN EXHIBITION PLACE; Architect: BBB Architects; Seating: 21,800

City: Toronto, Ontario, Canada; MLS Club: Toronto FC; Year Joined MLS: 2007

Playing Surface: artificial turf 2007-2009; natural grass since August, 2009 (Sportsnet, 2009)

Reductions in waste and pollution; Safeguarding land: In 2009 BMO Field achieved a 79.08\% waste diversion rate. This diversion rate means that $79.08 \%$ of all waste that was created by BMO Field did not go to a landfill; instead it was recycled or composted (Exhibition Place, 2010). BMO implemented many environmentally friendly policies to help achieve such a high waste diversion rate such as: hand towels and food waste were diverted to the compost; a switch to compostable cutlery and food serving/dispensing containers; replacing all non-recycling products at BMO Field with compostable Poly Lactide products (PLA) (Exhibition Place, 2010). In 2010, these policies continued to work as the waste diversion rate was $85.06 \%$ (Young, 2011).

Efficient and effective use of energy and resources; Reductions in air pollution; Utilization of renewable energy: BMO field uses $50 \%$ less energy than a stadium that would be built to meet the minimum requirements of the Model National Energy Code for Buildings (MNECB) (Ontario Construction Report, 2007). In 2009 renewable energy measures at Exhibition Place created an extra 1.81 Giga watt hours ( $1 \mathrm{GWh}=1$ billion watts) (Exhibition Place, 2009). In 2010 Exhibition Place reduced its use of grid electricity by $65.52 \%$ (Young, 2011). Steps taken toward renewable energy included constructing the first urban wind turbine in Canada and using LED streetlights (Ministry of the Environment Ontario, 2011). Exhibition Place also constructed a photovoltaic power generation plant which delivers its power generated to all of Exhibition Place, including BMO Field. A photovoltaic plant gets its energy from its collection of solar panels (Ministry of the Environment Ontario, 2011).

Water stewardship: untreated water was taken directly from Lake Ontario to water all trees on the grounds (Exhibition Place, 2009).

Promoting sustainability: The facility is accessible by \#29 Dufferin bus; \#511 Bathurst Streetcar, \$50 Lakeshore Streetcar and "Go Train" (Toronto FC, 2011). Also, trees are planted annually on the grounds of Exhibition Place for 3,004 trees by 2012 (Exhibition Place, 2009).

Sport Facility: BUCK SHAW STADIUM [on campus of Santa Clara University]; Architect: Herzogand De Meuron Seating: 10,300; City: Santa Clara, California, USA MLS Club: $\underline{\text { San Jose Earthquakes Year Joined }}$ MLS: 1996; Playing Surface: grass

Innovations in sustainability: All of the University's new projects and major renovations follow LEED standards" (SCU, 2012, n.p.)

Reductions in waste and pollution; Safeguarding land: Emphasis on reduction "of non-renewable resources, minimum pollution, and to live more lightly on the land." (SCU, 2012, n.p.)

Promoting sustainability: facility encourages use of public transit with train, bus and Ride Match, a commuter service) availability.

Sport Facility: CENTURYLINK FIELD; Architect: Ellerbe Becket in association with Loschky Marquardt and


Nesholm (LMN) a Seating: 67,000; City: Seattle, Washington, USA MLS Club: Seattle Sounders FC Year Joined MLS: 1998; Playing Surface: FieldTurf

Innovations in sustainability: FieldTurf (made from "35,000 recycled ground up tennis shoes and 30,000 recycled ground up tires" (CenturyLink, 2012, para. 4).

Reductions in waste and pollution; Safeguarding land: recycling program instituted; all cups sold are compostable; compostable food packaging utilized; landfill items are sorted to remove compostable items (CenturyLink, 2012).

Efficient and effective use of energy and resource; Reductions in air pollution; Utilization of renewable energy: Installed 3,750 Solyndra solar panels on the roof generating over $830,000 \mathrm{kWh}$ of electricity on an annual basis for a $21 \%$ annual utility cost reduction; highly efficient lighting systems (CenturyLink, 2012).

Water stewardship: low-flow water fixtures that are scheduled to save over 1,342,000 gallons of water annually (CenturyLink, 2012).

Promoting sustainability: encourages public transport; situated near train and bus system (CenturyLink, 2012).

Sport Facility: COLUMBUS CREW STADIUM; Architect: NBBJ (Griffith, 2011); Seating: 20,145

City: Columbus, Ohio, USA; MLS Club: Columbus Crew; Year Joined MLS: 1994

Playing Surface: natural grass

Reductions in waste and pollution; Safeguarding land: In 2004, this facility sent 100 tons of trash to the landfill, including 51,000 plastic bottles (SWACO Begins, 2005). In 2005, the facility partnered with the Solid Waste Authority of Central Ohio (SWACO) and recycled 6 tons of cardboard, plastics and bottles (Our Sports Central: Releases, 2006). In 2007, recycling involved 14 tons of material (Remy, 2008) and in 2009, 19 tons were recycled (Columbus Sports, 2010). SWACO's recycling message is displayed on scoreboard during home games (SWACO, 2008).

Efficient and effective use of energy and resources; Reductions in air pollution; Utilization of renewable energy: To celebrate Earth Day, 2011, all power at the facility was offset by renewable energy wind sources. The power saved during this game was enough to run an average USA home for 8 years (Crew Communications, 2011).

Promoting sustainability: During Earth Day 2011, fans were given packets of seeds to plant (Crew Communications, 2011).

Water stewadship: Jani-King International, the official cleaning provider, uses environmentally friendly products and is water conscious when providing services (Jan King, 2011).

Sport Facility: DICK'S SPORTING GOODS PARK; Architect: Populous; Seating: 18,186

City: Commerce City, Colorado, USA; MLS Club: Colorado Rapids; Year Joined MLS: 1996

Playing Surface: natural grass

Reductions in waste and pollution; Safeguarding land: Partnered with "We Don't Waste", a Denver-based organization that collects surplus food from restaurants and venues and distributes to those in need (We Don't Waste, 2011); significantly increased waste diversion rate. April 22, 2011 game was a "Play Clean" night that encouraged recycling; half-time recycling challenge held (MLS W.O.R.K.S., 2011).

Efficient and effective use of energy and resources; Reductions in air pollution; Utilization of renewable energy: January, 2010 facility partnered with Rocky Mountain Greener Venues to specifically improve in: energy conservation and efficiency; water conservation and efficiency; responsible materials and waste management; transportation and air quality; green buildings; local food and agriculture, environmentally preferable purchasing; green economy and community connections (Rocky Mountain Greener Venues Partnership, 2009).

Promoting sustainability: July 20, 2011 game had signs to encourage "Big Save", a program to encourage reductions in home energy use (Colorado Rapids Media Relations, 2011). Bus \#88 RTD stops at the facility.

Sport Facility: GILLETTE STADIUM Architect: Populous (HOK Sport) Seating:

City: Foxborough, MA, USA MLS Club: New England Revolution: Year Joined MLS: 2002

Playing Surface: FieldTurf Duraspine PROP system $\left[1^{\text {st }}\right.$ facility in North America to install this new system; surface if FIFA 2-star rated]

Water stewardship: "grey" water or drainage water is reused after wastewater treatment.

Efficient and effective use of energy and resource; Reductions in air pollution; Utilization of renewable energy: Timing devices shut down lights after hours.

Sport Facility: HOME DEPOT CENTRE; Architect: Rossetti; Seating: 27,000

City: Carson, California, USA; MLS Club: Los Angeles Galaxy \& Chivas USA ;Year Joined MLS: 1996 and

2005; Playing Surface: natural grass

Reductions in waste and pollution; Safeguarding land: Facility managed by AEG. The Home Depot Center works with Waste Management and the Long Beach Conservation Corps to divert as much waste from the landfill as possible (Home Depot Centre, 2011b). Each year they achieve a minimum of $50 \%$ waste diversion rate (The Home Depot Center, 2011b). Beginning in 2011 they began to recycle a wider range of materials that would 
normally be sent to the landfill, materials such as electronics, wood pallets and hazardous waste (The Home Depot Center, 2011b). New paper and plastic bins were added to the Home Depot Center for fans to properly dispose their waste (Home Depot Center Communications, 2011).

Efficient and effective use of energy and resources; Reductions in air pollution; Utilization of renewable energy: The Home Depot Center is aiming to reduce their energy consumption by $15 \%$ by the end of 2011 (The Home Depot Center, 2011b). They are doing this by monitoring energy use across California and when it is at peak times the Home Depot Center reduces its energy (The Home Depot Center, 2011b). They have also installed motion sensor lights to make sure that lights are not on when they are not needed (The Home Depot Center, 2011b).

Water steardship: The Home Depot Center uses a grey water reclamation system which is used for plants and industrial processing and cooling (The Home Depot Center, 2011b). Grey water is water that was once used for activities like laundry and bathing that can be recycled for other uses. In 2009 they replaced all urinals with zero-gallon flush urinals. That year they recycled $83 \%$ of all water (The Home Depot Center, 2011b).

Promoting sustainability: facility is accessible by the Los Angeles Metro Transportation Authority (MTA), by bus or rail. As well as by Carson Circuit Transit. (Home Depot Center, 2011a).

Sport Facility: JELD-WEN FIELD; Architect: A.E. Doyle, Morris H. Whitehouse (Soccerway, 2011),

AECOM (architects of 2010 renovation) (AECOM, 2011); Seating: 19,000 (Portland Timbers, 2011c) City: Portland, Oregon; MLS Club: Portland Timbers; Year Joined MLS: 2009 Playing Surface: FieldTurf Duraspine (Jeld-Wen Field, 2010)

Reductions in Waste and Pollution, Safeguarding Land: Jeld-Wen Field takes several measures to reduce the amount of waste they produce. They have 90 recycling bins located throughout the stadium, all office products and cardboard is recycled, leftover food from the concessions are donated to local charities, food scraps are composted, cooking oil is recycled, and the bathrooms are equipped with automatic towel and soap dispensers (Jeld-Wen Field, 2011). All cleaning products used at Jeld-Wen Field are green certified (Jeld-Wen Field, 2011).

Efficient and effective use of energy and resources; Utilization of renewable energy: Jeld-Wen Field uses light fixtures that turn off automatically when there is no one in the room, compact fluorescent light bulbs are used and all housekeeping machinery is green certified (Jeld-Wen Field, 2011). Having an artificial playing surface reduces the amount of water needed to maintain the field (Jeld-Wen Field, 2010). Jeld-Wen Field also use low-flow plumbing fixtures to reduce water use (Giegerich, 2011).

Promoting Sustainability: Jeld-Wen Field is accessible by Portland's TriMet Max light rail and bus services with extra buses running on game day. The Max station is across the street from Jeld-Wen Field and accessible by the Blue and Red line (Portland Timbers, 2011b). In 2009 Jeld-Wen Field improved its recycling and waste management so much that it became "Recycle at Work Certified"." Recycle at Work Certified" is given to buildings and businesses in Portland that become more environmentally friendly by implementing Portland's five recycling steps (Jeld-Wen Field, 2011). In 2011 Jeld-Wen Field was awarded LEED Silver Certification due to its high building sustainability (Portland Timbers, 2011a).

Sport Facility: LIVESTRONG SPORTING PARK; Architect: Populous; Seating: 18,467

City: Kansas City, Kansas, USA; MLS Club: Sporting Kansas City; Year Joined MLS: 1995

Playing Surface: Natural grass with SubAir under soil heating and cooling system (Livestrong Sporting Park, 2011).

Reductions in Waste and Pollution, Safeguarding Land \& Efficient and effective use of energy and resources: A Global Spectrum managed facility (subsidiary of Comcast Spectrum) that has "Step Up" program that commits to saving energy, reducing, reusing and recycling (Global Spectrum, 2011).

Promoting sustainability: Facility is accessible via bus on the 101 Minnesota/State Ave. route and the stop is at Village West.

Sport Facility: PIZZA HUT PARK; Architect: HKS; Seating: 20,500

City: Frisco, Texas, USA; MLS Club: FC Dallas; Year Joined MLS 1995; Playing Surface: Natural Grass

Reductions in waste and pollution; Safeguarding land: Colorful and visible recycle containers are used throughout the stadium for recycle collection (Sullivan, 2010). Containers that are 46 tons collect $23 \%$ of all waste as recyclables (Sullivan, 2010).

Efficient and effective use of energy and resource; Reductions in air pollution; Utilization of renewable energy: Carbon offsetting with $100 \%$ of the electricity used during the game offset by renewable wind energy (MLS W.O.R.K.S., 2011). Most lights at stadium are timed to go out at midnight (Sullivan, 2010). Indoor lights have motion detectors to shut off automatically when not in use (Sullivan, 2010).

Water stewardship: All water drainage from the field and the seating area is funneled and pumped into a retention pond. The water is then used to irrigate the field (Sullivan, 2010). The water supply is supplemented by two collection wells on the property (Sullivan, 2010). 
Sport Facility: RED BULL ARENA; Architect: Rossetti Architects; Seating: 25,000

City: Harrison, New Jersey, USA; MLS Club: New York Red Bulls; Year Joined MLS: 1994

Playing Surface: Natural Grass (Cox, 2008)

Reductions in waste and pollution; Safeguarding land: Facility sits on land that was once occupied by abandoned industrial factories that contaminated the land. These factories were demolished and the contaminated soil was removed so Red Bull Arena could be constructed on the clean land (Enivronmental Protection Agency, 2010). Promoting sustainability: Facility is accessible by PATH Trains and NJ Transit, Harrrison Station. (Red Bull Arena, 2011).

Sport Facility: RIO TINTO STADIUM; Architect: Rossetti Architects (Rossetti, 2011); Seating: 20,000 (Rio Tinto, 2011b) City: Salt Lake City, Utah; MLS Club: Real Salt Lake; Year Joined MLS: 2004

Playing Surface: Natural Grass (Rio Tinto, 2011b)

Reductions in waste and pollution: Rio Tinto Stadium uses Tork products for their napkins and bathroom towels. Tork tissues are 100 percent recycled fibers using chlorine free bleaching technology and are EcoLogoCM certified (Tork, 2009). Rio Tinto Stadium uses 180 Tork Matic hand towel systems in public restrooms and nine touchless Tork dispensing systems in premium seating areas (Tork, 2009). They also use 145 Tork Xpressnap napkin dispensers are used (Tork, 2009).

Promoting Sustainability: UTA TRAX, Salt Lake City's rail transit, has several stops within a fifteen minute walk of Rio Tinto Stadium (Rio Tinto Stadium, 2011). Rio Tinto Stadium's naming rights are given to Rio Tinto, a mining company who has strict environmental policies (Rio Tinto, 2011a).

Sport Facility: ROBERTSON STADIUM [John O'Quinn Field on campus of University of Houston]; Architect; Harry Payne Seating: 32,000 City: Houston, Texas, USA MLS Club: Houston Dynamo Year Joined MLS: 2006 Playing Surface: natural grass

Innovations in sustainability: June 2010, a feasibility study was completed and the University decision to demolish and rebuild the stadium on the same site; facility will seek LEED certification.

Sport Facility: TOYOTA PARK; Architect: Rossetti Architect's (The Original Wringer, 2009); Seating: 22,000 City: Bridgeview, Illinois; MLS Club: Chicago Fire; Year Joined MLS: 1997 Playing Surface: Grass (Uponor, 2011)

Promoting Sustainability: On April $22^{\text {nd }}, 2010$, forty trees were planted at Toyota Park for the fortieth anniversary of Earth Day (Chicago Fire, 2010). Toyota Park is accessible by the Chicago subway orange line. A Toyota Park express bus leaves the midday station every 20 minutes, 2 hours before a game. Busses leave every 30 minutes after a game returning to midday station (Toyota Park, 2011).

Sport Facility: ROBERT F. KENNEDY MEMORIAL STADIUM Architect: George A. Dahl Seating: 56,000

City: MLS Club: D.C. United Year Joined MLS: 1996

Playing Surface: grass [Prescription Athletic Turf]

Promoting sustainability: encourage cycling to the stadium and bike locking stations are available for use; encourage public transit use of METRO rail

\section{Discussion}

The purpose of the current investigation was to better understand how sport communicates its participation in environmental sustainability (ES). To answer this inquiry, this study focused on sport facilities that were home to a professional Major League Soccer (MLS) franchise during 2011; specifically, the facilities' website communications on ES were analyzed.

Hitchcock and Willard (2009) acknowledged the "focus on facilities" (p. 164) that often accompanies organizational interest in sustainability. And, while there certainly exists an "opportunity for leagues and teams to do a better job of communicating their efforts with regard to environmental issues" (Ciletti, Lanasa, Ramos, Luchs and Lou, 2010, p.74), often, teams are just tenants within the sport facility. Therefore, it is incumbent upon the facility owners to similarly improve communications surrounding environmental practices to enhance brand perceptions. Indeed, Ciletti et al., (2010) noted that environmentally responsible organizations were seen in a more positive light; in this regard therefore, efforts to communicate an organizational commitment to ES would seem to be defensible.

In the current study, the results support that each facility's management team showed at least some activity in ES and had taken steps to engage in some level of sustainability communications; this represents a base level of participation in what is interpreted as an evolving concept that refers to communications about sustainability 
issues (Signitzer \& Prexl, 2008). Specifically, communications related environmental sustainability by the sport facilities will now be discussed.

\subsection{Waste Reduction}

Hitchcock and Willard (2009) noted that "a number of organizations have achieved the goal of zero waste to landfill" (p. 56). This zero status goal was not the communicated state at the sport facilities hosting MLS games. The web-based communications did, however, indicate that there was a movement to waste management programs as $76.4 \%$ of the facilities under study communicated some type of sustainability waste management strategy. This sustainability movement was expressed quantitatively by four of the facilities. At BMO Field a total of $79.08 \%$ to $85.06 \%$ of their waste was diverted from landfills annually, this included hand towels, compostable cutlery and food containers, along with food waste that was diverted for composting. Columbus Crew Stadium communicated that they recycled 19 tons of cardboard, plastics and bottles. The Home Depot Center communications indicated a minimum of $50 \%$ of their waste from landfills annually and that this included electronics, wood pallets and hazardous waste. Also, Pizza Hut Park communicated that $23 \%$ of all of their waste collected was recycled. Additionally, multiple sport facilities' web communications indicated a participation in waste management programs with a variety of strategies, albeit, without quantifying their resulting diversion rates. For instance, expanded recycling programs included saving resources from a demolition project (BC Place); a half-time recycling challenge and a food diversion program (Dick's Sporting Goods Park); cooking oil recycling (Jeld-Wen Field); and the use of recycled fibers and chlorine free technology in napkins and bathroom towels (Rio Tinto Stadium). It was concluded, thus, that waste diversion was a direction that the facilities were heading and that represented a movement towards sustainability; but only $23.5 \%$ were quantitatively communicating their diversion rates at this point in time.

\subsection{Energy Efficiency}

Shafiullah, Amanullah, Ali, Jarvis, \& Wolfs (2011) noted the "critical need for a robust and sustainable power transmission and distribution system which is intelligent, reliable, and environment friendly, and overcomes various problems associated with the existing power system" (p. 1). Here, such a need could be met through the use of renewable energy (RE) options. Importantly, technology exists today to meet the call for sustainable renewable energy (Pacala \& Socolow, 2004) and can be seen. At the sport facilities hosting MLS, a number of energy strategies were reported, including the use of renewable energy strategies and energy efficiency strategies. For instance, Pizza Hut Park reportedly offset $100 \%$ of their carbon impact through wind projects. Also, PPL Park communicated that they had 100\% renewable energy credits. Further, BMO Field web-based communications revealed the use of energy from a wind turbine as well as photovoltaic power generations. This facility offered quantification of the energy savings; but, the figures were linked to the entire Exhibition Place, the area that houses the sport facility. CenturyLink Field also reported the use of photovoltaic energy. BC Place indicated an annual reduction in their carbon footprint and that carbon offsets were being purchased through the Pacific Carbon Trust; however, the quantification of this purchase was not communicated. Additionally, multiple energy efficiencies including timing devices on the lights (Gillette Stadium), an energy monitoring program (Home Depot Centre) and energy efficient fixtures and lights (BC Place; Dick's Sporting Goods Park). A total of $41.2 \%$ of the facilities under study did not communicate any information concerning energy efficiency. It was concluded that the majority of the sport facilities are moving towards energy strategies leading to sustainability as both energy efficiencies and renewable energy was noted in $64.7 \%$ of the web-based communications. As with waste reduction discussed above, the quantification of the energy sustainability status was generally lacking.

\subsection{Promoting Environmental Sustainability}

The most common communication surrounding ES was the ease of access to the sport facilities by public transit. While other initiatives were also noted, such as tree planting projects at BMO Field, tree seed giveaways at Crew Field, and the "Big Save" promotion at Dick's Sporting Field, promoting public transit was ubiquitous. While this seemingly unglamorous ES promotion may seem inconsequential, the beneficial impacts of enhanced public transit have been noted by Hitchcock and Willard (2009). The sport facilities communicating that public transportation system linked to the sport facility included examples such as street car and SkyTrain systems to BC Place; bus and train to BMO Field, Buck Shaw Stadium, CenturyLink Field, Home Depot Center, Jeld-Wen Field, and PPL Park. Additionally, the Buck Shaw Stadium communications promoted a service for commuters called Ride Match, and Toyota Park was linked to a subway. It was concluded that public transit was a fundamental component of the sustainability movement for the majority of the MLS sport facilities. 


\subsection{Water Stewardship}

Almost every nation is facing some form of water crisis (World Commission on Water, 2000). Compounding the issue is the fact that effective and efficient management of water usage is complex (van de Meene, Brown, \& Fairrelly, 2010; Varis, Biswas, Tortajada, \& Lundqvist, 2006). A total of six of the sport facilities indicated sustainability programs that related to water stewardship. For instance, grey water or reclaimed water was used for plants at the Home Depot Center and to irrigate the field at Pizza Hut Park. BMO Field utilized water from a local lake to water trees and the grounds, while Columbus Crew Stadium indicated the use of environmental cleaning products that aided to safeguard the water resources. Finally, Century Field communicated the use of low flow water fixtures - this was the only facility to quantify the water stewardship program indicating annual savings of over 1.3 million gallons of water.

\section{Conclusion}

This manuscript provided ES data from website communications by sport facilities that were home to a MLS franchise in 2011 and encouraged interpretations concerning their ES initiatives. Each of the sport facilities communicated a pattern towards some ES action(s), specifically in preventative environmental measures, and each has taken steps to communicate these actions. The sport facilities emphasized the preventative principles of environmental performance outlined by Glavic and Lukman (2007) as renewable resources, resource minimization, and recycling were communicated as the key areas of focus for sustainability. The secondary focus was on the control principles of sustainability outlined by Glavic and Luckman. For instance, recovery of products was not communicated; however, the use of remanufactured utensils and food containers with starch to make them biodegradable was indicated. Further, the removal of chlorine in products such as towels was stated and interpreted as a controlled attempt at the purification of products for the purposes of sustainability. Certainly, facility managers are attempting to integrate ES activities into the daily operations of venues. Moreover, it appears that communicating these initiatives is increasing in prominence. Continuous study however is necessary to fully understand ES in sport and the impact of their communication during this time of tremendous ecological change.

\section{References}

Aaker, D. A. (1996). Building strong brands. New York: The Free Press.

AECOM. (2011). Portland's new pitch. Retrieved December 12, 2011, from http://www.aecom.com/What+We+Do/Architecture/_stories/Portland's+new+pitch

AIBC. (2011). Stantec Architecture Ltd. Retrieved December 6, 2011, from $\mathrm{http} / /$ aibc.memberpro.net/main/body.cfm?menu=directory\&submenu=directoryBusiness\&mode=search\&r ecord_id $=1187 \&$ table_id $=1187$

American Recycler. (2010, January). Columbus sports teams team up for recycling success. Retrieved from: http://www.americanrecycler.com/0110/columbus004.shtml

Anschutz Entertainment Group (AEG). (2012). AEG 1Earth. Retrieved from http://www.aegworld.com

Anschutz Entertainment Group (AEG). (2010). AEG's 2010 Environmental Sustainability Report: AEG 1Earth. Retrieved from http://www.aegworld.com/media/swf/2010_sustainability_report/index.html

Badenhausen, K. (2008, September 9). Major League Soccer's Most Valuable Teams. Retrieved November 14, 2011, from http://www.forbes.com/2008/09/09/mls-soccer-beckham-biz-sports-cz_kb_0909mlsvalues.html

Barth, M., Godemann, J., Rieckmann, M., \& Stoltenberg, U. (2007). Developing key competencies for sustainable development in higher education. International Journal of sustainability in Higher Education, 8, 410-430. http://dx.doi.org/10.1108/14676370710823582

BC Place. (2011a). Impact. Retrieved December 6, 2011, from http://www.bcplacestadium.com/index.php/impact.html

BC Place. (2011b). Transit. Retrieved December 6, 2011, from http://www.bcplacestadium.com/index.php/interactive-map.html

Belson, K. (2011, October 25). Sports rally around green projects. The New York Times. Retrieved from http://www.nytimes.com2011/10/26/business/sports-industry-expands-its-environmental

Berry, L. (2000). Cultivating Service Brand Equity. Journal of the Academy of Marketing Science, 28, 128-137. http://dx.doi.org/10.1177/0092070300281012 
CenturyLink. (2012). CenturyLink Field: Venue information. Retrieved from http://www.centurylink.com/venue_information/

Chicago Fire. (2010). Chicago Fire 2010 Annual Report. Retrieved December 9, 2011, from http://issuu.com/chicagofire/docs/fire2010report

Ciletti, D., Lanasa, J., Ramos, D., Luchs, R., \& Lou, J. Y. (2010). Sustainability communication in North American professional sports leagues: insights from Web-site self-presentations. International Journal of Sport Communication, 3(1), 64-91.

Colorado Rapids Media Relations. (2011, July 13). Retrieved October 12, 2011, from http://www.coloradorapids.com/news/2011/07/make-big-save-xcel-energy-july-20

Constatineau, B. (2011, September 23). Empire falls, Whitecaps hope BC Place provides kick-start. Retrieved December 6, 2011, from http://www.vancouversun.com/sports/Empire+falls+Whitecaps+hope+Place+provides+kick+start/5450491 /story.html

Cox, D. (2008, October 28). Summary of Major League Soccer (MLS) Stadiums. Retrieved October 25, 2011, from

http://www.ottawa.ca/calendar/ottawa/citycouncil/ec/2009/02-24/8-CSS0013-Document\%201\%20Appendi x\%20G\%20-\%20MLS\%20Stadiums.pdf

Crenna, C. (2011, April 29). There's a green hue to Lenarduzzi's Whitecaps. Retrieved December 6, 2011, from http://www.bchydro.com/news/articles/conservation/2011/lenarduzzi_whitecaps_gogreen.html

Crew Communications. (2011, April 14). Crew Stadium Celebrates Earth Day. Retrieved October 6, 2011, from http://www.thecrew.com/news/2011/04/crew-news-notes-april-14

Darnall, N., \& Sides, S. (2008). Assessing the performance of voluntary environmental programs: Does certification matter? Policy Studies Journal, 36(1), 95-1117.

Davis, S. M., \& Dunn, M. (2002). Building the brand-driven business: Operationalizing your brand to drive profitable growth. San Francisco, CA: Jossey-Bass.

DeTombe, D. (2008). Towards sustainable development: A complex process. International Journal of Environment and Sustainable Development, 7, 49-62.

Drier, F. (2011, April 18-24). MLSE planning complex for Toronto FC, academy. Street \& Smith Sports Business Journal, 10.

Environmental Protection Agency. (2010). State Brownfields and Voluntary Response Programs: An Update from the States. Retrieved October 12, 2011, from http://epa.gov/brownfields/state_tribal/update2011/bf_states_report_2011.pdf

Exhibition Place. (2010). Exhibition Place Waste Diversion Program. Retrieved September 27, 2011, from http://www.compost.org/English/PDF/WRW_2010/Montreal/M\%20Dimaso,\%20Exhibition\%20Place\%20 Compost $\% 202010 \% 202 . p d f$

Giegerich, A. (2011, September 1). Timbers park ear high LEED status. Retrieved December 12, 2011, from http://assets.sustainablebusinessoregon.com/articles/2011/09/timbers-park-earns-high-leed-status.html

Gladden, J. M., Milne, G. R., \& Sutton, W. A. (1998). A conceptual framework for assessing brand equity in Division I college athletics. Journal of Sport Management, 12(1), 1-19.

Glavič, P., \& Lukman, R. (2007). Review of sustainability terms and their definitions. Journal of Cleaner Production, 15, 1875-1885.

Global Spectrum. (2011). Green Initiatives. Retrieved November 7, 2011, from http://www.global-spectrum.com/region/en/green-initiatives.aspx

Griffith, T. (2011). Tim Griffith. Retrieved October 3, 2011, from $\mathrm{http}: / /$ www.timgriffith.com/index.php\#mi=2\&pt=1\&pi $=10000 \& \mathrm{~s}=9 \& \mathrm{p}=9 \& \mathrm{a}=1 \& \mathrm{at}=0$

Heugens, P. (2006). Environmental issue management: Towards a multi-level theory of environmental management competence. Business Strategy and the Environment, 15, 363-376. 
Hitchcock, D., \& Willard, M. (2009). The Business Guide to Sustainability: Practical strategies and tools for organizations (2nd ed.). New York: Earthscan.

HKS. (2010, October 1). Press Releases. Retrieved October 25, 2011, from http://hksinc.com/news/search/press-release/2010-10-01/Sustainable-Sports-Strategies

Holmes, S. (2004, November 22). Soccer: Time to kick it up a notch. Retrieved November 9, 2011, from http://www.businessweek.com/magazine/content/04_47/b3909099.htm?campaign_id=search\%20Soccer:\% 20Time\%20To\%20Kick\%20It\%20Up\%20A\%20Notch

Home Depot Center. (2011a). Directions/Parking. Retrieved October 20, 2011, from $\mathrm{http}: / / \mathrm{www} \cdot h o m e d e p o t c e n t e r . c o m / c o n t e n t r i g h t . p h p ?$ section=parking\&page=public

Home Depot Center. (2011b). Going Green. Retrieved Ocotver 21, 2011, from $\mathrm{http}: / / \mathrm{www} \cdot$ homedepotcenter.com/contentright.php?section=aboutus\&page=aeg1 earth

Home Depot Center Communications. (2011, March 18). The Home Depot Center rolls out new fan recycling program, concession stand items and a restructured Club Seat program for the 2011 Season. Retrieved October 21, 2011, from $\mathrm{http}: / / \mathrm{www} . h o m e d e p o t c e n t e r . c o m / c o n t e n t r i g h t . p h p ? s e c t i o n=a b o u t u s \& p a g e=$ news_article\&news_id=1909

Huffington Post. (2011, November 9). Major Leaague Soccer Surpasses NBA And NHL In Per-Game Attendance. $\quad$ Retrieved November 14, 2011, from http://www.huffingtonpost.com/2011/11/08/major-league-soccer-surpa_n_1082593.html?ncid=edlinkusaol p00000003

Impact Montreal. (2011). Stade Saputo Expansion. Retrieved December 2011, 2011, from http://www.impactmontreal.com/en/stadium/stadium-expansion

Impact Soccer. (2011). Saputo Stadium. Retrieved December 12, 2011, from $\mathrm{http}: / / \mathrm{www}$. impactsoccer.com/stadium.php

Intergovernmental Panel on Climate Change (IPCC). (2007). Climate Change 2007. World Meteorological Organisation, Geneva, Switzerland. Retrieved from http://www.ipcc.ch

International Standard Organization (ISO). (2004). ISO 14004. Retrieved from http://www.standardpdf.com

Jan King. (2011). Green Cleaning Keeps Business on Top. Retrieved October 7, 2011, from http://www.janiking.com/Green_Cleaning_Keeps_Businesses_on_Top.aspx

Jasner, A. (2010, February 25). Clean and Green PPL Park to Open June 27. Retrieved October 27, 2011, from http://www.philadelphiaunion.com/news/2010/02/clean-and-green-ppl-park-open-june-27

Jeld-Wen Field. (2011). 2010 Renovation. Retrieved December 9, 2011, from http://jeld-wenfield.com/about/renovation

Jeld-Wen Field. (2011). Guest Guide. Retrieved December 12, 2011, from http://jeld-wenfield.com/guest-guide

Krippendorff, K. (2004). Content analysis: An introduction to its methodology (2nd ed.). Thousand Oaks, CA: Sage.

Livestrong Sporting Park. (2011). Livestrong Sporting Park Fact Sheet. Retrieved October 24, 2011, from http://www.sportingkc.com/stadium/fact-sheet

Lockwood, C. (2006, June). Building the green way. Harvard Business Review, 129-137.

Longman, J. (2007, July 8). Beckham Arrives to Find a Sport Thriving in Its Own Way. Retrieved November 14, 2011, from http://www.nytimes.com/2007/07/08/sports/soccer/08beckham.html?ex=1186372800\&en=8ac84814e27d5 $891 \& \mathrm{ei}=5070$

Mallen, C., \& Chard, C. (2011). A framework for debating the future of environmental sustainability in the sport academy. Sport Management Review, 14, 424-433. http://dx.doi.org/10.1016/j.smr.2010.12.002

Mallen, C., \& Chard, C. (2012). What could be" in Canadian sport facility environmental sustainability. Sport Management Review, 15(2), 230-243. http://dx.doi.org/10.1016/j.smr.2011.10.001 
Mallen, C., Stevens, J., \& Adams, L. (2011). A content analysis of environmental sustainable research in a sport-related journal sample. Journal of Sport Management, 25, 20-256.

Mallen, C., Stevens, J., Adams, L., \& McRoberts, S. (2010a). An assessment of the environmental performance of an international multi-sport event: Understanding the organizational barriers to event sustainability. European Sport Management Quarterly, 10, 97-122. http://dx.doi.org/10.1080/16184740903460488

Mallen, C., Adams, L., Stevens, J., \& Thompson, L. (2010b). Environmental sustainability in sport facility management: A Delphi study. European Sport Management Quarterly, 10, 36-389. http://dx.doi.org/10.1080/16184741003774521

Metro Montreal. (2011). Station Pie-IX. Retrieved December 12, 2011, from http://www.metrodemontreal.com/green/pieix/index.html

Miloch, K., \& Pederson, P. (2006). Sports information directors and the media: An analysis of a highly symbiotic and professional relationship. Journal of Contemporary Athletics, 2, 91-103.

Ministry of the Environment Ontario. (2011, March 10). Ministers Awards for Environmental Leaders. Retrieved September 28, 2011, from http://www.ene.gov.on.ca/environment/en/about/EnvironmentalExcellence/STDPROD_083064.html

MLS. (2011a). Clubs. Retrieved November 9, 2011, from http://www.mlssoccer.com/clubs

MLS. (2011b). General Overview. Retrieved November 9, 2011, from http://web.archive.org/web/20080625214719/http://web.mlsnet.com/about/

MLS. (2011c). MLS Executives. Retrieved November 14, 2011, from http://www.mlssoccer.com/executives

MLS. (2011d). Greener Goals. Retrieved November 15, 2011, from http://www.mlssoccer.com/mlsworks/greener-goals

MLS Soccer. (2011, July 21). MLS W.O.R.K.S. gives back to the NY/NJ community as part of the 2011 AT\&T MLS All-Star Celebration. Retrieved October 27, 2011, from LA Galaxy: http://www.lagalaxy.com/news/2011/07/mls-works-gives-back-nynj-community-part-2011-att-mls-all-starcelebration

Muret, D. (2006, December 4-10). Green Days for sports design. Street \& Smith's Sports Business Journal. Charlotte, NC: American City Business Journals.

Muret, D. (2011, June 20). Strong debut. Retrieved October 25, 2011, from http://www.sportsbusinessdaily.com/Journal/Issues/2011/06/20/Facilities/Livestrong.aspx

Muret, D. (2011, August 29-September 4). Canadian arena will be first to use rainwater for ice ockey. Street \& Smith's Sports Business Journal. Charlotte, NC: American City Business Journals.

Olstoorn, X., Tyteca, D., Wehrmeyers, W., \& Wagner, M. (2001). Environmental indicators for business: a review of literature and standardization methods. Journal of Cleaner Production, 9, 453-463. http://dx.doi.org/10.1016/S0959-6526(01)00005-1

Ontario Construction Report. (2007, September). Design improves seating, provides powerful advertising for Toronto. Retrieved $\quad$ September $28, \quad 2011, \quad$ from http://content.yudu.com/Ayd00/BBBBMOField/resources/index.htm?referrerUrl=http\%3A\%2F\%2Fwww. google.ca\%2Fsearch\%3Fgcx\%3Dw\%26sourceid\%3Dchrome\%26ie\%3DUTF-8\%26q\%3Dontario\%2Bcons truction $\% 2$ Breport $\% 2 \mathrm{Bbmo} \% 2 \mathrm{Bfield}$

Pacala, S., \& Socolow, R. (2004). Stabilization wedges: Solving the climate problem for the next 50 years with current technologies. Science, 305(5686), 968-972. http://dx.doi.org/10.1126/science.1100103

Patton, M. (2002). Qualitative research and evaluation methods (3rd ed.). London: Sage.

Paquette, J., Stevens, J., \& Mallen. C. (2011). The IOC: An interpretation of environmental sustainability, 1994-2008. Sport in Society, 14(3), 355-369. http://dx.doi.org/10.1080/17430437.2011.557272

Plunkett, J. (2011). Major League Soccer. Retrieved November 9, 2011, from $\mathrm{http}: / / \mathrm{www}$.plunkettresearchonline.com

Portland Timbers. (2011a, August 31). JELD-WEN Field awarded prestigious LEED ${ }^{\circledR}$ green building $\begin{array}{lllll}\text { certification. } & \text { Retrieved } & \text { December } & \text { 2011, } & \text { from }\end{array}$ 
http://www.portlandtimbers.com/news/2011/09/jeld-wen-field-awarded-prestigious-leed\%C2\%AE-green-b uilding-certification

Portland Timbers. (2011b). Parking \& Directions. Retrieved December 12, 2011, from http://www.portlandtimbers.com/parking-directions

Portland Timbers. (2011c). Stadium Renovation. Retrieved December 9, 2011, from http://www.portlandtimbers.com/stadium-renovation

PPL EnergyPlus. (2011). About Us. Retrieved November 4, 2011, from http://www.pplenergyplus.com/AboutUs/

PPL Park. (2011). About PPL Park. Retrieved October 28, 2011, from http://www.philadelphiaunion.com/ppl-park/about

Red Bull Arena. (2011). Stadium Facts. Retrieved October 25, 2011, from http://www.redbullarena.us/arena/stadiumfacts.aspx

Red Bulls Reader. (2010, January 21). Red Bulls to open Red Bull Areans with Santos on March 20. Retrieved October 25, 2011, from https://redbullsreader.wordpress.com/2010/01/21/red-bulls-to-open-red-bull-arena-with-santos-on-march-2 $0 /$

Remy, J. (2008, September 9). SWACO, The Crew \& New Albany Schools Announce Contest. Retrieved October 6, 2011, from http://www.franklincountyohio.gov/fc/content/press/swaco09-09-08.cfm

Rio Tinto. (2011a). Environmental stewardship. Retrieved December 5, 2011, from http://www.riotinto.com/ourapproach/17194_environmental_stewardship.asp

Rio Tinto. (2011b). Stadium Facts. Retrieved December 3, 2011, from http://www.riotintostadium.com/stadium_facts.php

Rio Tinto Stadium. (2011). Public Transportation. Retrieved December 3, 2011, from http://www.riotintostadium.com/public_transportation.php

Rocky Mountain Greener Venues Partnership. (2009, March 19). Rocky Mountain Greener Venues Partnership for Sustainable Communities. Retrieved October 12, 2011, from $\mathrm{http}: / / w w w . e p a . g o v /$ region8/greenervenues/details.html

Rossetti. (2011). Rio Tinto- Real Salt Lake MLS Stadium. Retrieved December 3, 2011, from $\mathrm{http}: / /$ www.rossetti.com/projects/sports/RioTinto

Rossetti. (2003). Rossetti: Home Depot National Training Center. Retrieved October 20, 2011, from http://www.rossetti.com/projects/sports/HomeDepotTrainingCenter

Santa Clara University (SCU). (2012). Sustainability. Retrieved from http://en.wikipedia.org/wiki/Santa_Clara_University\#sustainabilty

Schwartz, B. (2009). Environmental strategies as automorphic patterns of behavior. Business Strategy and the Environment, 18, 192-206. http://dx.doi.org/10.1002/bse.567

Shafiullah, G. M., Amanullah, M. T. O., Ali, A. B. M. S., Jarvis, D., \& Wolfs, P. (2011). Prospects of renewable energy - a feasibility study in the Australian context. Renewable Energy, 39(1), 183-197. http://dx.doi.org/10.1016/j.renene.2011.08.016

Shriberg, M. (2002). Institutional assessment tools for sustainability in higher education: Strength, weaknesses, and implications for practice and theory. International Journal of Sustainability in Higher Education, 3(3), 254-20. http://dx.doi.org/10.1016/S0952-733(02)00006-5

Signitzer, B., \& Prexl, A. (2008). Corporate sustainability communications: Aspects of theory and professionalization. Journal of Public Relations Research, 20(1), 1-19. http://dx.doi.org/10.1080/10627260701726996

Soccerway. (2011). Jeld-Wen Field. Retrieved December 9, 2011, from http://www.soccerway.com/venues/united-states/pge-park/

Sportsnet. (2009, August 5). For Madrid, the grass is real. Retrieved September 26, 2011, from http://www.sportsnet.ca/soccer/2009/08/05/realgrass_bmofield_realmadrid/ 
Starik, M., \& Marcus, A. (2000). Introduction to the special research forum on the management of organizations in the natural environment: A field emerging from multiple paths, with many challenges ahead. Academy of Management Journal, 43(4), 539-546. http://dx.doi.org/10.2307/1556354

Stemler, S. (2001). An overview of content analysis. Practical assessment. Research Evaluation, 7(17), Retrieved from http://PAREonline.net/getvn.asp?v=7\&n=17

Sullivan, B. (2010). Pizza Hut Park: Texas' First 'Green' Stadium. Retrieved November 8, 2011, from http://www.friscogreenliving.com/people-projects/pizza-hut-park-texas-first-green- stadium/

SWACO begins recycling with 30\% reduction goal. (2005, May). American Recycler. Retrieved from $\mathrm{http}: / / \mathrm{www}$.americanrecycler.com/0505swaco.shtml

The Original Wringer. (2009, November 18). Conversations in Soccer - Gino Rossetti of Rossetti Architects. Retrieved December

8 , 2011 , $\mathrm{http}$ //theoriginalwinger.com/2009-11-18-conversations-in-soccer-gino-rossetti-of-rossetti-architects

Toronto FC. (2011). Directions. Retrieved September 26, 2011, from http://wwrontofc.ca/directions

Tork. (2009, April). New Soccer Stadium in Salt Lake Chooses Tork. Retrieved December 5, 2011, from http://www.torkusa.com/news/365-newsletter/20091/365-Talking-Tork-Everyday-April-2009/Sustainabilit y-Story---Rio-Tinto-Stadium/New-Soccer-Stadium-in-Salt-Lake-City-Chooses-Tork/

Toyota Park. (2011). Public Transportation. Retrieved December 8, 2011, from http://www.toyotapark.com/venue/public-transportation.aspx

Uponor. (2011). Testimonials. Retrieved December 8, 2011, from http://www.uponor.ca/en/Misc/Testimonials/Chris-Bennett/Overview.aspx

United Nations Environment Programme (UNEP). (2007). International Panel on Climate Change (IPCC) Fourth Assessment Report: Climate Change 2007 - AR4 Synthesis Report. United Nations: Geneva, Switzerland. Retrieved from http://www.ipcc.ch

United Nations (UN) World Commission on Environment and Development Brundtland Report. (1987). 96 ${ }^{\text {th }}$ Plenary meeting, United Nations General Assembly, Report to the World Commission on the Environment and Development. Retrieved from http://www.on.org/documents/ga/res/42/ares/42-187.htm

United Nations Environment Programme (UNEP). (2007). Global environment outlook 4: Summary for decision makers. Retrieved from http://www.unep.org/geo/geo4/media/GEO4\%20SDM_launch.pdf

United States (U.S.) Green Building Council. (n.d.). What LEED is. Retrieved July 31, 2011, from http://www.usgbc.org

van de Meene, S., Brown, R., \& Fairrelly, M. (2010). Capacity attributes of future urban water management refines: Projects from Australian sustainability practitioners'. Water Science \& technology, 61(9), 2241-2250. http://dx.doi.org/10.1016/j.gloenvcha.2011.04.003

Varis, O., Biswas, A., Tortajada, C., \& Lundqvist, J. (2006). Megacities and water management. Water Resources Development, 22(2), 377-394. http://dx.doi.org/10.1080/07900620600684550

Wallace, L., Wilson, J., \& Miloch, K. (2011). Sporting Facebook: A content analysis of NCAA organizational sport pages and Big 12 conference athletic department pages. International Journal of Sport Communications, 4, 422-444.

We Don't Waste. (2011). We Don't Waste: About Us. Retrieved October 11, 2011, from http://www.wedontwaste.org/mission

Weber, R. (1985). Basic content analysis. Beverly Hills, CA: Sage.

Winn, M., \& Kirchgeorg, M. (2005). The siesta is over: A rude awakening from sustainability myopia. In S. Sharma \& M. Starik (Eds.), Research in Corporate Sustainability, Strategic Capabilities and Competitiveness (pp. 232-258). Northampton, MASS: Elgar.

World Commission on Water. (2000). Report of the World Commission on Water. Water Resources Development, 16(3), 289-320.

Yin, R. (1994). Case study research: Design and methods (2nd ed.). Thousand Oaks, CA: Sage. 
Young, D. (2011, February 9). Exhibition Place: Media Centre. Retrieved September 30, 2011, from http://www.explace.on.ca/media/press_releases/articles92.php

\section{Appendix A: Facility Web Sites}

BC Place- http://www.bcplacestadium.com/

BMO Field- http://bmofield.com/

Buck Shaw Stadium -http://www.santaclarabroncos.com/information/facilities/buckShaw

Century Link Field- http://www.centurylinkfield.com/

Columbus Crew Stadium- http://crewstadium.com/

Dicks Sporting Goods Park- http://www.dickssportinggoodspark.com/

Gillette Stadium- http://www.gillettestadium.com/

Home Depot Center- http://homedepotcenter.com/

Jeld Wen Field- http://jeld-wenfield.com/

Sporting Park (formerly Livestrong sporting park) - http://www.sportingkc.com/stadium

FC Dallas Stadium (formerly Pizza Hut Park)- http://www.fcdallasstadium.com/

PPL Park- http://www.philadelphiaunion.com/ppl-park

Red Bull Arena- http://www.redbullarena.us/

Rio Tinto Stadium- http://www.riotintostadium.com/index2.php

Robertson Stadium- http://www.houstondynamo.com/stadium/robertson

Toyota Park- http://www.toyotapark.com/

RFK Stadium- http://www.dcunited.com/stadium

\section{Copyrights}

Copyright for this article is retained by the author(s), with first publication rights granted to the journal.

This is an open-access article distributed under the terms and conditions of the Creative Commons Attribution license (http://creativecommons.org/licenses/by/3.0/). 